Natalia Perehonchuk, PhD (Candidate of Psychological Sciences), associate professor, Department of Psychology and Social Work, Vinnitsa State Pedagogical University, 32, Ostrozkoho Str., Vinnitsia, Ukraine

\title{
FORMATION OF FUTURE PSYCHOLOGISTS' PROFESSIONAL COMPETENCE IN MODERN EDUCATIONAL ENVIRONMENT
}

In terms of integration, democratisation, socio-economic changes in the society, significant reforms are taking place in the sphere of education. The educational environment is becoming more and more spontaneous and global. The main task of a subject of the educational environment is supporting its professional competence in terms of dynamic and constant changes of everyday life. One of the key moments of the education modernisation is the creation of pedagogical conditions and efficient ways of future psychologist's professional competence formation in accordance with modern demands. The article is aimed at reviewing the issue of a future psychologist's professional competence formation in the modern educational environment. Basing on the psychological literature review the following conditions of future psychologist's professional competence formation have been distinguished: refocusing on the changing and structuring of future psychologist's inner state in the process of the formation of knowledge and skills in the interaction between a student and a teacher; development of a future psychologist's skills and desire to study throughout life; professional competence has a personal character and includes a man's subjective experience, his/her needs, interests, desires, feelings, and value orientations; profound knowledge, acquired in the process of professional training, creates potential opportunity for a student to develop in a professional way; reflexive environment as a precondition for the personal development gives an opportunity for self-examination and self-correction of socio-psychological and professional recourses. The following features of the modern educational environment contributing to the formation of future psychologists' professional competence have been identified: unique character, paradoxical feature, openness, uncertainty; variability (formal, informal education). The organisation of the modern educational environment has its principles, rules and conditions and plays a significant role not only in the formation of professional competence, but also professional and personal development of a future psychologist.

Keywords: professional competence, reflexive environment, person-centered education, competence approach, future psychologists.

Рецензент: д. психол. н., доц. О. М. Паламарчук

Подано до редакиіï 14.11.2016

UDC: 159.923 .2

Inna Khorzhevska,

PhD (Candidate of Psychological Sciences), associate professor, Department of Psychology, Petro Mohyla Black Sea State University, 10, Desantnykiv Str., Mykolaiv, Ukraine

\section{PROFESSIONALISM AND AN INDIVIDUAL'S PROFESSIONAL DEVELOPMENT}

The article analyses the issues of an individual's professional development, examines different approaches to it. The development of a professional is a result of a personality's formation in the professional activity; it is connected with general personality development and acquisition of new experience, knowledge, abilities, and with transformation of motivation and interests of a person.

Keywords: professionalism, personality of the worker, professional formation of a personality, personal development.

\section{Introduction}

Scientists consider professionalism as a combination of general education with the skills acquired in the process of work in a certain organisation, under specific conditions of its in many ways unique system of distribution and organisation of labour.

Most authors consider personal and professional development as complementary and interdependent proc- esses (O. O. Derkach [8], Ye. O. Klymov [3], N. V. Kuzmina [6]).

Profession is referred to as a certain kind of socially useful work; the emergence of the profession is provided by the division and cooperation of labour under specific technical and organisational conditions of production and the combination of knowledge and practical skills 
achieved by an employee as a result of education or experience obtained.

The issues of the formation of employee's individuality, his/her positive attitude to work, interest in the contents of work, satisfaction with it increasingly attract psychologists, sociologists and managers' attention.

There is no doubt that the formation of a personality, his/her individuality, system of attitudes to the world, society, to him-/herself is involved into his/her activity. And professional activity has a peculiar place among various types of individual's social activities. The professional activity gives most people an opportunity to satisfy the diversity of their needs, reveal their abilities, and assert themselves as individuals.

It is necessary, therefore, to conduct a special psychological study of an individual's professional development and its impact on the formation of a personality.

\section{Discussion}

Foreign authors have a certain approach to the study of an individual in the professional activity that leads to the acquisition of professionalism. This approach involves isolated study of "professional personality types" (the term introduced to the science by E. Shpranger). This approach is based on the fact that a similar type of human activity results in the formation of similar personality traits, due to the similarity of the professional requirements to the psychological and physiological characteristics of a person. Similar conditions of work and life, production targets, similar ways of social growth indicate a similarity of people's behaviour in terms of manners, speech, and communication; determine common interests, needs, attitudes and so on.

Within one profession there are several specialties, and if a profession is a kind of activity, a specialty is a type of activities within the same profession, a set of specific knowledge and skills. The choice of a specialty depends on the scope of work, the stage of the production process, applied tools, equipment and so on. Both a profession and a specialty are determined by the characteristics of the work's content, including items of work, the means of labour and the features of its organisation (division, cooperation).

The education system is focused on training specialists for popular (mass) occupations with the possibility of receiving particular specialisation at the final stage of training. This is because the process of learning is also a kind of a production process, and according to the current approach to the organisation of labour, the main efficiency factor is the flow method, mass production, low cost. There are no funds for the individual training in business, and to implement this training, teachers should be familiar with the trainees' future workplace peculiarity. So, this training is possible if the workplace is known in advance, the teacher has an opportunity to study its peculiarity and the company has an opportunity to pay for such training. It is clear that within the general educational system, the training is possible only for obtaining typical elements of professional knowledge, a specialty. Now numerous educational institutions are engaged not in a specialised training, but in general education. Some large companies have saved or created their own systems of training, but even these institutions cannot prepare professionals for the variety of jobs. The degree of this diversity is increasing significantly due to the complete desire to start one's own businesses and to organise work for oneself.

As a rule, researchers understand the professional development of an individual as growth, development, positive integration of personal qualities and abilities, professional knowledge and skills into the professional work. But the most important thing is the qualitative transformation of an individual's inner world, which leads to a fundamentally new method of his/her personality formation and life journey - the creative self-realisation in a profession. The main psychological condition and a form of professional development of an individual is his/her professional socialisation [5; 7].

This approach, despite its desirability, is not quite accurate. In our opinion, there is a need to show negative or destructive aspects of an individual's personal professional development. A social aspect, setting a certain career direction in life, serves as an "oppression" that brings people to the desired condition. However, for several reasons, this function of the society may be insufficient. Despite continuous development, individual's self-improvement, his/her possibilities are limited. For this or that person the holistic knowledge of the world is unavailable, unaffordable within one's lifetime, as long as the amount of knowledge is endless. Such knowledge is only available to the mankind in general, and only as a perspective.

Professional development is a product of the individual's activity. In this sense, professional development can also turn out to be a negative change in a personality in the process of the individual's work and acquiring professional experience in a professional environment with "dirty" standards and values of the professional community. It can also happen as a process of realisation of negative aspects of accumulated work experience, in which different types of destructive behaviour are manifested.

The professional formation means an individual personal process, the main feature of which is based on a personal choice.

The issue related to a professional formation and personal development was discussed in the works by national and foreign scientists: B. G. Ananiev [1], L. S. Vygotskiy [2], E. O. Klimov [3], I. S. Kon [4], L. F. Obukhova, L. B. Filonov, S. Freud, E. Erickson [8], and others.

So, the founder of the scientific and psychological approach to the problem of individual's professional formation was F. Parfons. He was the first to say that every profession has a corresponding set of psychological and physiological characteristics. And person's success and satisfaction with the professional activity depends on the degree of compliance of individual personality traits with the requirements of the profession.

Then, Sh. Byuller and D. Syuper confirmed that the search for the profession was determined by childhood 
dreams about future job, role playing games at the previous age stages, and achievements of a certain level of personal development.

A. Adler believes that career choice is based on a person's desire of hypercompensation of his/her own personality's dissatisfied properties, so a person chooses exactly the profession that refers to his/her individual features the least, but can help to assert him-/herself in his/her own eyes. Partially this approach to the choice of the profession is confirmed in the present study [9].

E. Rowe connects the individual's professional development with the nature of previous child-parent relationships. She finds out that working with people is chosen by those ones, in whose families the emotional atmosphere of acceptance and cooperation, the methods of persuasion and encouragement, a clear division of family functions dominated. The field of art is selected when an emotional side played the leading role in the relationships between parents and their children. The occupations that involve dealing with things are mostly selected by people from families, where atmosphere of alienation, misunderstanding, and punishment methods prevailed [9].

In a period of economic transition, a person's career choice can be determined by the types of the most popular specialties of the day.

Touching the heights of professionalism is a long way to go. It is preceded by a thought-out organisation of not only educational process for children of preschool and junior school age, but focused introduction to the profession and properly organised vocational education. It should be combined with a general personal development, involvement into the activity that makes it possible to develop the individual algorithm of behaviour in regard to professionalism. Training can be considered complete and valid if it is complemented by ongoing commitment to the professional growth.

Professionalism is defined as the highest stage in the development of a person as a subject of knowledge, work and communication. The criterion level of professionalism is the extent of conformity of the professional's knowledge and skills to the modern achievements of science and practice in this area.

Professionalism as an essential acmeological category is considered in the broad context of activity and personality's manifestations. Undoubtedly, an individual is developing in the process of carrying out the professional activity. Professionalism includes substructures from a dialectical unity: professionalism of the activity and professionalism of the individual.

There are different views on the essence of professionalism. According to A. K. Markova [7], professionalism psychology reveals the conditions and laws of a human progress towards professionalism. Psychology of professionalism in this sense describes the psychological criteria and levels of professionalism, stages and steps on the way to it, age and individual peculiarities of a professional.
This understanding of a professionalism and professional skills reflects mainly the things related to the activity aspect, whereas the personality and its development in the work seem to be in the background.

In our opinion, a promising direction is the study of professionalism as the examination of the subject of work in close connection with the development (individual and professional). B. H. Ananiev pointed to the need for basic research of maturity, noting that it is the most important periods of personal development, which are characterised by highly creative and social activity [1]. Under his leadership in 1965 in Leningrad, the school of experimental research of an individual was founded, and the given studies have broken the existing notions of maturity as a period of "fossilisation". This aspect of the problem high efficiency of activity and achievements - has become a crucial prerequisite for the formation of acmeology as a science.

Currently, acmeology is defined as the science that emerged at the intersection of natural, technical and humanitarian disciplines, studying patterns and mechanisms of human development at the stage of maturity, and especially when reaching the highest level in this development [7].

Such a broad understanding of acmeology created the preconditions for the formation and development of its different fields. Due to public demand, direction associated with acmeology achievements in professional activities, i.e. professionalism has received the greatest development. Therefore, the object of this field of acmeology is the professional activity, which deals with objective and subjective factors helping and hindering to reach the heights of professionalism. Thus, in the context of achieving professionalism, the issues related to the achievement of high efficiency or performance, individual professional development, optimisation activities, the development of new methods and algorithms for solving professional problems and others were considered.

The achievement of professionalism in acmeological sense is associated with the development of personal qualities (commitment, initiative, self-discipline), character traits (tenacity, perseverance, consistency), intellectual qualities associated with perfection and enrichment of professional skills, the creative potential of the individual and his/her moral development. Thus, professionalism is associated with an individual's professional development.

An individual's professional development is the process of a personality formation (in the broad sense) and its professionalism in self-development, professional activities and professional interactions [3]

The summary of reviewed researches $[3 ; 7 ; 8 ; 9]$ makes it possible to suggest that the following structural changes of a personality take place in the process of its professional development:

1. Change of the individual's orientation: needs;

- expansion of interests and changing the system of

- updating achievement motives; 
- increasing needs for self-realisation and selfdevelopment;

2. Extension of experience and training:

- the development of competence;

- the development and expansion of skills;

- mastering new algorithms of solving professional problems;

- enhancement of creativity.

3. The development of complex partial abilities.

4. The professionally important qualities determined by specific activities development.

5. The development of individual qualities.

6. Enhancement of psychological readiness.

There are different levels of professionalism development. Their assessment should be based on the system acmeological indicators, where personality and activity aspects should be defined. It includes:

- Performance or efficiency of operations;

- The level of qualifications and professional competence;

- Optimal and labour intensities;

- Accuracy and reliability of the activity;

- Organisation;

- Low dependence on external factors;

- Knowledge of modern sense and contemporary ways of solving professional problems;

- Stable high performance indexes;

- The level of individual administrational and professional qualities development;

- The level of achievement motivation;

- The opportunity to develop as an individual;

- Focus on achieving positive socially relevant purposes.

If a specialist's activity is characterised by high professionalism based on a certain system of indicators, then he/she is considered to have a high acmeological level.

\section{ЛІТЕРАТУРА}

1. Ананьев Б. Г. Избранные психологические труды: в 2 т. / Б. Г. Ананьев. - Москва : Педагогика, 1980. Вып. 1 / Изд. А. А. Бодалева, Б. Ф. Ломова. -338 с.

2. Выготский Л. С. Проблема возраста / Собр. соч. в 6 т. / Л. С. Выготский. - Т. 4. - Москва : Педагогика, 1984. - С. 244-269.

3. Климов Е. А. Профессиональное самоопределение / Е. А. Климов. - М., 2004. - 120 с.

4. Кон И. С. В поисках себя : личность и ее самосознание / И. С. Кон. - Москва : Политиздат, 1984. - 335 c.

5. Корнеева Л. Н. Психологический аспект влияния профессиональной деятельности на личность / Л. Н. Корнеева . - М. : Просвещение, 1991. - 218 с.

\section{REFERENCES}

1. Ananyev, B. G. (1980). Izbrannye psikhologicheskie trudy: $v 2$ t. [Selected works on psychology: in 2 vols.]. Moscow: Pedagogika [in Russian].
Up to now, it has been considered that a person's professional life should consist of the introduction to a specific position in his/her youth and continuation of work in the chosen field up to retirement. Such a professional career demanded a carefully chosen profession and preparation for it. When a person started working, he/she was expected to lay the foundation of his career for all his/her life and try to climb the career ladder as soon as possible.

This point of view has undergone changes as the adults' development may lead to the changes of professional needs and goals. Moreover, in a technically advanced and economically uncertain world, the nature of work is changing so fast, and the number of jobs is being cut down in such amounts that the imperative of "one profession for the entire life" is no longer applicable. People can go to work in other firms and organisations. They may hold another position in the same company or organisation (such as a promotion or when going for administrative work). Most people do not change their profession fundamentally; at the same time, nowadays it is considered unusual to start and finish one's professional life in the same workplace or within one official vertical. This is especially true for women who interrupt their work for three to five years or even more being on maternity leave. Being middle-aged they are ready to focus their energy on some other kind of activities. It is the work that helps them to find a new sense of their capabilities and form meaningful relationships.

\section{Conclusion}

Thus, the professional development of an individual is associated with the development of a personality in general, with the assimilation of new experiences, knowledge, skills and the transformation of person's motivation and interests.

6. Кузьмина Н. В. Оценка профессиональной деятельности учителя / Н. В. Кузьмина. - М. : Высш.шк., 1990. - 208 c.

7. Маркова А. К. Мотивация специалиста. Пути освоения профессиональной деятельности / А. К. Маркова. - М., 1996. - 152 с.

8. Психологическое обеспечение профессиональной деятельности / Изд. Р. С. Никифоровой. - СанктПетербург., 2004. - 360 с.

9. Самоукина Н. В. Психология и педагогика профессиональной деятельности / Н. В. Самоукина. М. : “Тандем”, 1999. - 352 с.

2. Vygotskiy, L. S. (1984). Problema vozrasta [The problem of age]. (Vols. 4). (pp. 244-269). Moscow: Pedagogika [in Russian]. 
3. Klimov, Ye. A. (2004). Professionalnoe samoopredelenie [Professional self-identification]. Moscow [in Russian].

4. Kon, I. S. (1984). V poiskakh sebya: lichnost i ee samosoznanie [Looking for one's place in the world: personality and its self-awareness]. Moscow: Politizdat [in Russian].

5. Korneyeva, L. N. (1991). Psikhologicheskiy aspekt vliyaniya professionalnoy deyatelnosti na lichnost [Psychological aspect of the influence of professional activities on a personality]. Moscow: Prosveschenie [in Russian].

6. Kuzmina, N. V. (1990). Otsenka professionalnoy deyatelnosti uchitelya [Evaluation of teacher's work]. Moscow: Vysshaya shkola [in Russian].
7. Markova, A. K. (1996). Motivatsiya spetsialista. Puti osvoyeniya professionalnoy deyatelnosti [Motivation of a specialist. Ways of mastering professional activities]. Moscow [in Russian].

8. Nikiforova, R. S. (Ed.). (2004). Psikhologicheskoe obespechenie professionalnoy deyatelnosti [Psychological support of professional activities]. St. Petersburg [in Russian].

9. Samoukina, N. V. (1999). Psikhologiya $i$ pedagogika professionalnoy deyatelnosti [Psychology and pedagogy of professional activities]. Moscow: "Tandem" [in Russian].

Інна Михайлівна Хоржевська, кандидат психологічних наук, дочент кафедри психології, Чорноморський державний університет імені Петра Могили, вул. Десантників, 10, м. Миколаїв, Україна

\section{ПРОФЕСІОНАЛІЗМ ТА ПРОФЕСІЙНИЙ РОЗВИТОК ОСОБИСТОСТІ}

Розвиток професіонала є результатом формування особистості в професійній діяльності й професійних взаємодіях, а також в особистісному просторі. Професіоналізм - це сполучення загальної освіти з уміннями і навичками, що здобуваються у процесі роботи у конкретній організації, у специфічних умовах розподілу та організації праці. Проблеми становлення особистості працівника, формування у нього позитивного ставлення до праці, інтересу до змісту роботи, задоволеності працею є актуальною і в теоретичному і в практичному розумінні. У процесі діяльності відбувається формування особистості, складається їі індивідуальність, виробляється система відношень до світу, до суспільства, до себе. Особливе місце серед різноманітних видів соціальної діяльності особистості займає професійна діяльність. Саме професійна діяльність надає більшості людей можливість задовольнити все різноманіття своїх потреб, розкрити свої здібності, ствердитися як особистість. Професійний розвиток може проявлятися і як негативна зміна особистості у процесі існування індивіда у професійному середовищі або засвоєння професійного досвіду. Під професійним становленням розуміється індивідуальний особистісний процес, основним елементом якого є особистий вибір. Професійна підготовка може вважатися повноцінною та діючою, якщо вона доповнюється постійним прагненням до професійного зростання. Професіоналізм визначається як вищий щабель у розвитку людини як суб'єкта пізнання, праці, спілкування. При цьому критерієм рівня професіоналізму є ступінь відповідності знань, умінь і навичок фахівця сучасним досягненням науки та практики у цій області. Професіоналізм як найважливіша акмеологічна категорія розглядається, у широкому контексті: у діяльнісному та особистісному проявах. Професійний розвиток особистості пов'язаний 3 розвитком особистості взагалі, із засвоєнням нового досвіду, знань, вмінь та із трансформацією мотивації й інтересів конкретної людини.

Ключові слова: професіоналізм, особистість фахівця, професійне становлення особистості, особистісний розвиток.

Инна Михайловна Хоржевская, кандидат психологических наук, дочент кафедры психологии, Черноморский государственный университет имени Петра Могиль, ул. Десантников, 10, г. Николаев, Украина

\section{ПРОФЕССИОНАЛИЗМ И ПРОФЕССИОНАЛЬНОЕ РАЗВИТИЕ ЛИЧНОСТИ}

Развитие профессионала является результатом формирования личности в профессиональной деятельности и профессиональных взаимодействиях, а также в личностном пространстве. Профессионализм - это комбинация общего образования с умениями и навыками, которые приобретаются в процессе работы в конкретной организации, в специфических условиях распределения и организации работы. Проблемы становления личности специалиста, формирование у него положительного отношения к работе, интереса к содержанию работы, удовлетворенности работой являются актуальными как в теоретическом, так и в практическом понимании. В процессе деятельности происходит становление личности, складывается ее индивидуальность, формируется система отношений к миру, к обществу, к себе. Особое место среди разных видов социальной деятельности личности занимает профессиональная деятельность. Именно профессиональная деятельность предоставляет большинству 
людей возможность удовлетворить все многообразие своих нужд, раскрыть свои способности, утвердиться как личность. Профессиональное развитие может проявляться и как негативное изменение личности в процессе существования индивида в профессиональной среде, во время усвоения профессионального опыта. Под профессиональным становлением понимается индивидуальный личностный процесс, основным элементом которого является личный выбор. Профессиональная подготовка может считаться полноценной и действующей, если она дополняется постоянным стремлением к профессиональному росту. Профессионализм определяется как высшая ступень в развитии человека как субъекта познания, деятельности, общения. При этом критерием уровня профессионализма является степень соответствия знаний, умений и навыков специалиста современным достижениям науки и практики в этой области. Профессионализм как самая важная акмеологическая категория рассматривается в широком контексте: в деятельностном и личностном проявлениях. Профессиональное развитие личности связано с развитием личности вообще, с усвоением нового опыта, знаний, умений и с трансформацией мотивации и интересов человека.

Ключевые слова: профессионализм, личность специалиста, профессиональное становление личности, личностное развитие.

Подано до редакиіï 15.11.2016

Рецุензент: д. псих. н., проф. Л. П. Журавльова

УДК: 159.9: 316613

Владислав В'ячеславович Папуша, старший викладач кафедри педагогіки, психології і корекиійної освіти, Рівненський обласний інститут післядипломної педагогічної освіти, вул. Чорновола, 74, м. Рівне, Украӥна

\section{ВІКТИМНА ПОВЕДІНКА ПІДЛІТКА: ФОРМИ ПРОЯВУ ТА ЇХ АНАЛІЗ}

Віктимна поведінка властива більшою або меншою мірою кожній особистості, незалежно від віку, статі, освіти. Особливо гостро вона має прояв у підлітковому віці, для якого властиві швидкі й інтенсивні життєві зміни. Саме в иееи час спостерігається найвищза схильність підлітка потрапляти в ситуації, пов'язані з небезпекою для життя і здоров'я. У ицьому дослідженні, щзо має пошуковий характер, терміном «віктимна поведінка» позначено свідомі або несвідомі легковажні, аморальні або протиправні дії та вчинки підлітка, які можуть слугувати приводом для вчинення злочину. Також подано порівняльний аналіз основних форм прояву віктимної поведінки підлітків.

Ключові слова: підліток, віктимна поведінка, форми, типи, види прояву.

Підлітковий вік є достатньо інтенсивним періодом життя, що висуває особливі вимоги до особистості та іiі активності, до вміння перебудовувати та переглядати наявні думки і оцінки. Цей віковий період відрізняється високою інтенсивністю процесів соціалізації та індивідуалізації. Дорослішання характеризується інтенсивними пошуками свого місця у світі, суспільстві, системі соціальних стосунків, а також розширенням усвідомлення власних особливостей, здібностей з точки зору відповідності вимогам соціуму. У зв’язку з цим підлітку необхідно погоджувати свої потреби з очікуваннями оточуючих та вимогами соціальних норм. Необхідність такого погоджування часто пов'язана із значними труднощами, котрі й стають причиною виникнення суперечностей у розвитку підлітка. Ці суперечності можуть протікати в гострій формі, зумовлюючи сильні емоційні переживання, порушення у поведінці та взаєминах із дорослими та ровесниками.
Одна із найбільш яскравих характеристик підліткового віку - особистісна нестабільність, яка виявляється в емоційній лабільності, тривожності, суперечливості почуттів, моральній нестійкості, коливаннях самооцінки. За умови недостатніх внутрішніх ресурсів і несприятливої загальної життєвої ситуації підліток стає найбільш уразливим до стресу, а тяжкі життєві умови можуть провокувати прояв віктимності [3; 5; 9].

Наукове визначення віктимної поведінки, здійснене дослідниками $[2 ; 4 ; 6 ; 10]$, охоплює коло проблем, у розв'язанні яких виявляються різні підходи та інтерпретація феномену, що досліджується.

Аналіз наукових джерел 3 означеної проблеми дозволив виділити такі основні напрямки, за якими проводиться вивчення цього феномену: структурна організація віктимної особистості [7]; класифікація та типологія відхилень у розвитку та поведінці підлітків [8; 14]; психологічна детермінація прояву віктимної поведінки $[1 ; 10 ; 13 ; 16]$; форми та причини виник- 